\title{
Response of Valencia Orange Trees to Foliar Application of Chelated Manganese
}

\author{
Aly M. Ibrahim \\ Horticultural Research Institute, Agricultural Research Centre, Giza, Egypt
}

Received: $27 / 12 / 2020$

\begin{abstract}
Optimum fruit size is one of the most important parameters determining the profitability of citrus production to acquire high marketing value. The study was conducted on Valencia orange trees (Citrus sinensis L.) budded on sour orange rootstock (Citrus aurantium). Trees were planted at $5 \times 5 \mathrm{~m}$ spacing (168 trees/feddan) growing in sandy soil under flood irrigation at a private orchard in Wadi Elmolaak area at Ismailia, Governorate, Egypt. An experiment was conducted on mature trees of Valencia orange to study the effect of different concentrations of manganese spread at different times on the incidence of chlorosis, yield, and mineral contents. Trees sprayed with chelated $\mathrm{Mn}$ at $0.3 \%$ in March, June, and September. Treated trees had less percentage of chlorosis than non-sprayed trees. The same treatments also have the largest yield. Nitrogen, potassium, and iron contents were decreased as the rate of Mn sprays increased. Nitrogen content was increased as the number of applications increased.
\end{abstract}

Keywords: Foliar Application, Manganese, Valencia orange, Macro and micronutrients, Yield

\section{INTRODUCTION}

Citrus occupies the largest fruit trees area in Egypt. Washington Navel orange is considered the most popular and widespread citrus variety. Efforts have been intensified to improve the cultural practices in order to raise citrus yield per acre. One of the most important cultural practices is the fertilization program. Foliar fertilizer rates are typically lower than soil fertilizer rates, but applications can be costlier. These applications which added only minimally to production costs, were able to increase returns and by several pounds per acre per year. Foliar fertilization also reduces nutrient accumulation in soil. Manganese is as essential constituent of the enzymes which are responsible for translocation of other essential elements within the plant, and for chlorophyll action of photosynthesis (Datta, 1968). The first important property of magnesium is the relatively high solubility of its salts. Magnesium has a structural role in chlorophyll, is required for ribosome integrity, and undoubtedly contributes to the structural stability of nucleic acids and membranes (Clarkson and Hanson, 1980). Foliar application of potassium, calcium and magnesium on citrus was found to increase yield and improve fruit properties; especially when sprayed during the proper period of growth (Maksoud et al., 2003; Boman, 2001; Cicala and Catara, 1994; Boman, 2002). Abd-Allah (2006) reported that, combination between nutrients i.e. Ca chelate $0.5 \%$ dipotassium hydrogen phosphate $1 \%$ significantly improved the yield of Washington navel orange trees. Yasseen and Manzoor (2010) reported that NPK fertilizers (calculated on the basis of age and foliage rather than on the basis of area) application in drip line in combination with foliar spray was helpful to improve production and quality of Kinnow mandarin fruits up to $63 \%$.

One of the major causes of manganese deficiency appears to be the alkaline reaction of the soil (Hilgeman, 1955). Trees grown in soils high in calcium carbonate show greater deficiency (Platt, 1968), since manganese exists in them in an unavailable form. In acid and sandy soils, manganese is usually present in a very soluble and highly available form, thus making it prone to leaching (Camp and Peach, 1939). Although manganese is present in various forms in most soils, additional applications are often necessary to ensure sufficient supplies to nutrient in an available form for growing citrus trees. Parker and Southwick (1941) found that foliage sprays of various Mn compounds corrected Mn deficiency symptoms in citrus trees.

The increment in fruit size due to magnesium application to citrus trees was reported by Huang et al. (1995) in China using Satsuma mandarin, Boman (2001) in Florida using Valencia orange, Quaggio et al.(2002) in Brazil using Sicilian lemon, Rattanpal et al. (2008) using Kinnow mandarin and Dawood et al. (2001) in Egypt using Washington navel orange trees. On the other hand, Miller and Bird (1998) using Midknight Valencia orange and Robyn Navel in South Africa found that spray applications of potassium fertilizers did not significant effects on fruit quality parameters including size.

The experiment reported here described the effects of foliar applications of Mn chelate at different concentrations and different number sprays on Valencia orange trees budded on sour orange rootstock in Wadi Elmolaak area at Ismailia, governorate.

\section{MATERIALS AND METHODS}

This field experiment was conducted during $2017 \& 2018$ seasons, in a private orchard of bearing Mn deficient as shown in Table (1), located in Wadi Elmolaak area in Ismailia Governorate.

Mature Valencia orange trees about 20-year- old budded on sour orange rootstock was selected for this experiment.

The soil was sandy in texture of $\mathrm{pH}$ 7.3-8.0. This study designed as factorial experimental with two factors; 1$)$ levels of chelated manganese spray $(0.0,0.1$, 0.3 , and $0.5 \%$. 2) Numbers of application spray in March (Just before blooming), March and June (after fruit set) and March, June, and September.

Volume 9 (1): 73-80 
Each treatment was replicated three times, one tree per each. The chelated Mn was technical disodium manganous ethylene diamine tetracetate dehydrate containing $12 \% \mathrm{Mn}$. Urea (urea contained less than $0.25 \%$ biuret) was added at the rate of $10 \mathrm{~g}$ per liter of sprayed nutrient (Wallace, 1966; Labanuskas et al., 1969). The control trees were sprayed with urea at the same concentration. Manganese sprayed was applied for two successive years to the same trees. The spraying was done by using a 10-liter capacity hand sprayer.

All trees received ammonium sulphate, calcium superphosphate, and potassium sulphate added at a rate of $1000 \mathrm{~g} \mathrm{~N}, 125 \mathrm{~g} \mathrm{P}_{2} \mathrm{O}_{5}$ and adopted in Wadi Elmolaak area at Ismailia, governorate. Irrigation was by the basin method.

Table (1): Some nutrient concentrations in soil and leaves of non-fruiting terminals of the experimental orchard

\begin{tabular}{lccc}
\hline Elements & Soil sample & Leaf sample & Satisfactory range \\
\hline Nitrogen (\%) & 207 & - & $2.2-2.7 \%$ \\
Phosphorus (\%) & 5 & 0.17 & $0.10-0.19 \%$ \\
Potassium (\%) & 114 & 1.30 & $0.7-1.5 \%$ \\
Calcium (\%) & 156 & 3.75 & $2.6-5.0 \%$ \\
Magnesium (\%) & 170 & 0.38 & $0.3-0.6 \%$ \\
Iron (ppm) & 53 & 52 & $50-150 \mathrm{ppm}$ \\
Zinc (ppm) & - & 24 & $25-100 \mathrm{ppm}$ \\
Manganese (ppm) & 16 & 14 & $25-100 \mathrm{ppm}$ \\
Copper (ppm) & 5.3 & 5.7 & $5-15 \mathrm{ppm}$ \\
Boron (ppm) & 0.6 & - & $30-100 \mathrm{ppm}$ \\
\hline
\end{tabular}

For chlorosis percentage, twenty twigs per tree were selected. Chlorotic and healthy leaves borne on these twigs were separately counted and expressed as percentages of the total leaf number. It was determined before each foliar application according to Dutt and Bohambota (1971). Yield per tree was determined at harvest time during early March. The leaf sample was taken in mid-October from non-fruiting spring tagged flushes as recommended by Chapman (1960). The age of the sample leaves was about seven months. The leaf samples were thoroughly washed with tap water. Rinsed twice with distilled water, dried to a constant weight an air-drying oven at $70^{\circ} \mathrm{C}$ the dried materials were then ground in a stainless steel rotary knife mill to 20 -mesh size. The ground dried materials of each sample were analyzed for total nitrogen, phosphorous, and potassium. Total nitrogen was determined by the micro-Kjeldahl Gunning method as described in the AOAC (2000). Phosphorus percentage was determined by using spekol spectrophotometer (Cottenie et al., 1982). Potassium was flame photo metrically assayed (Brown and Lilland, 1946). For the manganese, iron, and zinc determined, a portion of $0.5 \mathrm{~g}$ of the grounddried material of each sample was digested with hydrochloric acid (dry aching according to Chapman and Pratt (1965). Iron, zinc, and manganese (in ppm) were measured using atomic absorption spectrophotometer Perkin Elmer model 5000 according to Evenhuis and Deward (1980).

All the data were statistically analyzed according to Snedecor and Cochran (1980).

\section{RESULTS AND DISCUSSION}

Chlorosis percentage:

Data on chlorosis percentages of the trees are presented in Table (2). It is apparent that the chlorosis percentage was decreased in trees treated with manganese. After the $1^{\text {st }}$ spray in the first season, there was no effect due to treatment. However, after the $2^{\text {nd }}$ spray, the differences were detectable. In the second season, the trees showed a marked decrease in the magnitude of chlorotic leaves.

The percentage of chlorosis was decreased as the number of chelated Mn sprays increased (Table 2). Significant interaction effects have been noticed between main and sub-plot in the second season only. Generally, sprays of chelated $\mathrm{Mn}$ at $0.3 \%$ in March, June, and September proved to be superior in decreasing the chlorosis percentage as was reported to be due to its implication in the formation of chlorophyll molecules or its indirect effect as an activator or enzymes responsible for the per cusses of chlorophyll structure (Devlin, 1972). Meyer and Anderson (1970) observed that the manganese apparently plays indirect role in the synthesis of chlorophyll. It was shown that manganese sprays tended to decrease the percentage of chlorosis in the leaves of oranges (Manchand et al., 1971; Nasr, 1982) and Mandarin (Jotur, 1985). 
Table (2): Percentage of total leaves/shoot as affected by chelated manganese on the intensity of chlorotic leaves

\begin{tabular}{|c|c|c|c|c|c|c|c|c|c|c|c|c|c|c|c|c|c|c|c|c|c|c|c|c|c|c|}
\hline \multirow{4}{*}{$\begin{array}{c}\text { Chelated } \\
\text { Mn }\end{array}$} & \multicolumn{8}{|c|}{ February } & \multicolumn{8}{|c|}{ May } & \multicolumn{8}{|c|}{ August } & \multirow{4}{*}{ Av. } & \multirow{4}{*}{$\begin{array}{l}\text { \% ratio leaf } \\
\text { no. /shoot }\end{array}$} \\
\hline & \multicolumn{4}{|c|}{2017} & \multicolumn{4}{|c|}{2018} & \multicolumn{4}{|c|}{2017} & \multicolumn{4}{|c|}{2018} & \multicolumn{4}{|c|}{2017} & \multicolumn{4}{|c|}{2018} & & \\
\hline & \multicolumn{4}{|c|}{ No. of sprays } & \multicolumn{4}{|c|}{ No. of sprays } & \multicolumn{4}{|c|}{ No. sprays } & \multicolumn{4}{|c|}{ No. of sprays } & \multicolumn{4}{|c|}{ No. of sprays } & \multicolumn{4}{|c|}{ No. of sprays } & & \\
\hline & 1 & 2 & 3 & Av. & 1 & 2 & 3 & Av. & 1 & 2 & 3 & Av. & 1 & 2 & 3 & Av. & 1 & 2 & 3 & Av. & 1 & 2 & 3 & Av. & & \\
\hline Control & 73 & 58 & 69 & 66 & 72 & 68 & 75 & 72 & 69 & 66 & 3 & 68 & 66 & 72 & 72 & 70 & 65 & 64 & 71 & 67 & 51 & 72 & 72 & 65 & 68 & 100 \\
\hline 0.3 & 68 & 68 & 47 & 61 & 38 & 41 & 26 & 35 & 53 & 58 & 3 & 38 & 32 & 16 & 19 & 22 & 49 & 44 & 31 & 41 & 28 & 16 & 14 & 19 & 38 & 44 \\
\hline 0.5 & 57 & 81 & 66 & 68 & 21 & 27 & 18 & 22 & 63 & 63 & 3 & 54 & 13 & 10 & 5 & 9 & 36 & 43 & 29 & 33 & 10 & 6 & 3 & 6 & 32 & 52 \\
\hline 1.0 & 66 & 73 & 71 & 70 & 28 & 19 & 19 & 22 & 51 & 51 & 3 & 61 & 22 & 15 & 12 & 16 & 47 & 40 & 37 & 41 & 18 & 9 & 7 & 11 & 36 & 47 \\
\hline Means & 66 & 70 & 63 & 66 & 40 & 39 & 35 & 38 & 58 & 60 & 55 & 58 & 33 & 28 & 27 & 29 & 49 & 45 & 42 & 45 & 27 & 26 & 24 & 25 & 43 & 61 \\
\hline
\end{tabular}

LSD (0.05):

Levels of Mn spray

18.3

10.7

20.1

17.9

8.1

No. of applications (B)

N.S.

N.S

20.1

3.7

7.0

Interaction: $(A) \times(B)$

7.8

5.3

6.0

8.2

6.1 
Yield:

The data in Table (3) show that all manganese treatments caused yield increases when compared with control. The percentage increases varied in the first season as compared with the second season. The percentage increases in the 2-year means were 11.11, 29.12 , and $25.48 \%$ for sprays of chelated manganese at $0.1,0.3$ and $0.5 \%$, respectively as compared with the control. The highest significant values were found in trees sprayed with manganese at 0.3 and $0.5 \%$, but no significant difference was found in between their two concentrations.

Three applications proved to be the most effective of all treatments. Concerning the interaction, the data show that under any concentration of manganese sprays yield weight increased as the number of applications increased.

In general, yield weight of Valencia oranges significantly increased as the rate of chelated manganese increased. Spraying chelated manganese at $0.3 \%$ in March, June, and September resulted in the best crop. These results were, generally, in agreement with those obtained by Nasr (1982), who found that manganese application increased the yield of Washington navel oranges planted in sandy soil. Increased leaf magnesium of citrus leaves when the trees were sprayed with magnesium salts was reported by Haggag et al. (1987), El-Fouly et al. (2010).

Table (3): Effect of chelated manganese spray on yield weight per tree $(\mathrm{kg})$ of Valencia orange trees

\begin{tabular}{|c|c|c|c|c|c|c|c|c|c|c|c|c|}
\hline \multirow{3}{*}{$\begin{array}{c}\text { Chelated } \\
\%\end{array}$} & \multicolumn{12}{|c|}{ Date of application } \\
\hline & \multicolumn{4}{|c|}{2017} & \multicolumn{4}{|c|}{2018} & \multicolumn{4}{|c|}{ Mean of two seasons } \\
\hline & Mar. & $\begin{array}{c}\text { Mar., } \\
\text { June }\end{array}$ & $\begin{array}{l}\text { Mar., } \\
\text { June, } \\
\text { Sept. }\end{array}$ & Av. & Mar. & $\begin{array}{c}\text { Mar., } \\
\text { June }\end{array}$ & $\begin{array}{l}\text { Mar., } \\
\text { June, } \\
\text { Sept. }\end{array}$ & Av. & Mar. & $\begin{array}{c}\text { Mar., } \\
\text { June }\end{array}$ & $\begin{array}{l}\text { Mar., } \\
\text { June, } \\
\text { Sept. }\end{array}$ & Av. \\
\hline Control & 49.2 & 50.9 & 56.3 & 52.1 & 51.3 & 45.2 & 51.2 & 50.3 & 48.0 & 53.7 & 50.7 & 50.8 \\
\hline T1 & 58.8 & 66.7 & 49.5 & 58.3 & 65.6 & 70.9 & 53.7 & 63.4 & 62.2 & 68.8 & 51.6 & 60.9 \\
\hline $\mathbf{T 2}$ & 74.5 & 63.0 & 67.8 & 62.4 & 76.0 & 70.1 & 68.5 & 71.5 & 75.3 & 66.5 & 68.1 & 70.0 \\
\hline T3 & 59.7 & 56.9 & 49.9 & 55.5 & 69.5 & 60.8 & 58.8 & 63.0 & 64.6 & 58.8 & 54.3 & 59.2 \\
\hline Means & 60.5 & 59.4 & 55.9 & 58.6 & 65.6 & 61.7 & 58.1 & 61.8 & 63.1 & 60.5 & 56.9 & 60.2 \\
\hline
\end{tabular}

L.S.D. (0.05)

\begin{tabular}{lccc} 
Levels of Mn spray (A) & 7.2 & 9.6 & 10.9 \\
No. of applications (B) & 3.1 & 5.2 & 4.1 \\
\hline Interaction: $(\mathbf{A}) \times(B)$ & 2.6 & 3.8 & 5.9 \\
\hline
\end{tabular}

\section{Mineral content:}

The data were shown in Table (4) revealed the leaves from orange trees treated with chelated Mn sprays generally containing lower $\mathrm{N}$ and $\mathrm{K}$ concentrations than on analogous leaves from control. This decrease in $\mathrm{N}$ and $\mathrm{K}$ from spraying with $\mathrm{Mn}$ can be associated possibly with analogues in orange yield. Data showed also that foliar application of chelated Mn in March, June, and September were the most effective for increasing the level of nitrogen concentration, whereas March application was the most effective for potassium concentration. On the other hand, the different number of applications was much less effective for the concentration of $\mathrm{N}$ and $\mathrm{K}$.

The phosphorus content was not affected by level or number applications of chelated manganese. 
Table (4): Leaf concentration of N, P and K elements of Valencia orange sprayed with chelated manganese in both 2017 and 2018 seasons

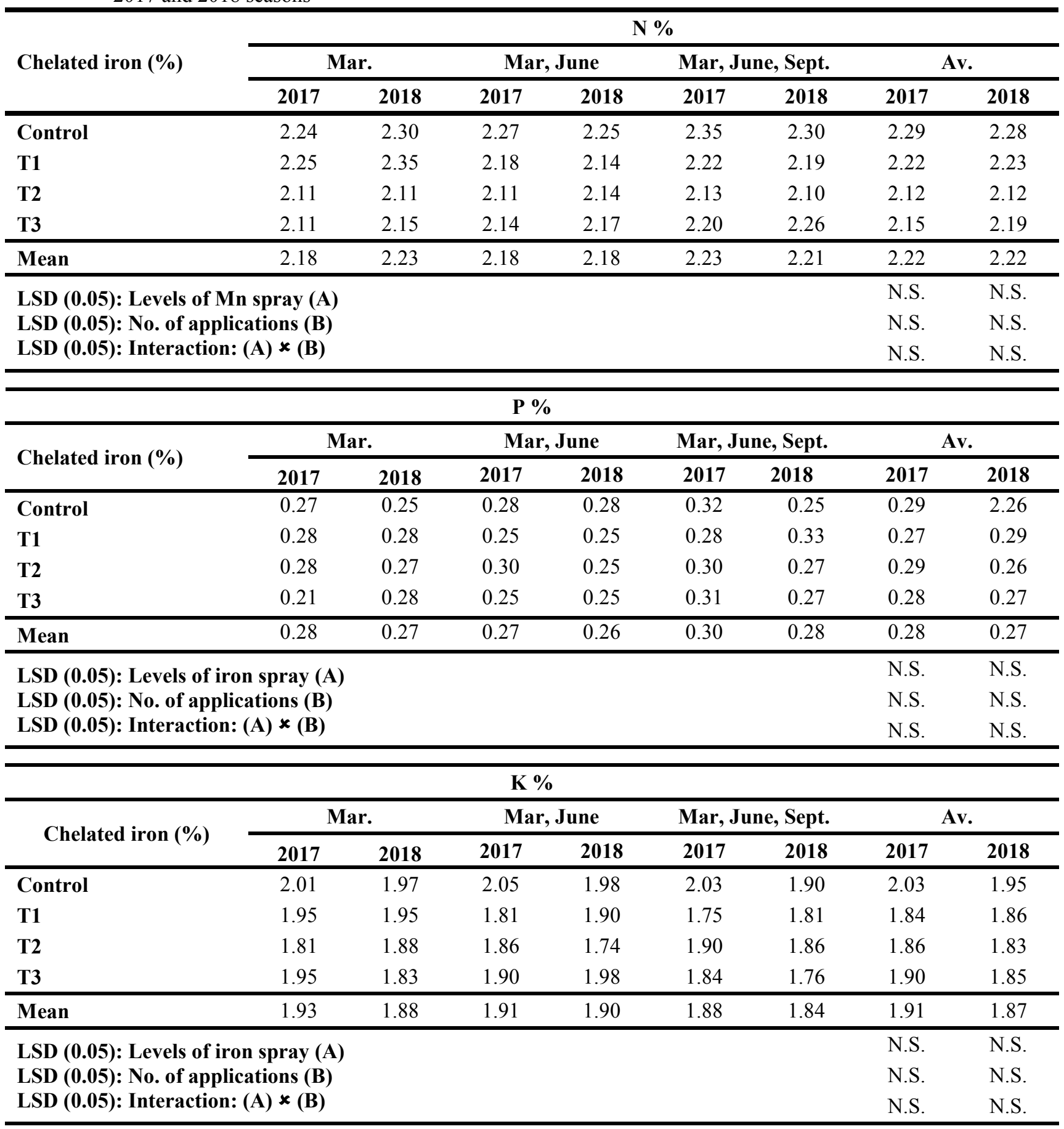

Data shown in Table (5) revealed that the manganese concentrations in orange leaves were increased as the rate of Mn spray increased.

As retard the effect of number of applications, results indicated that sprays of chelated $\mathrm{Mn}$ in March, June, and September were the most effective. The high efficiency of three applications in increasing the manganese content of Valencia leaves internal and external factors would influence the penetration of nutrients into the leaves (Devlin, 1972).

Under El-Tahreer conditions, the temperature and relative humidity in September were probably lower than that in March or June. It is also known that the process of absorption is influenced by the stage of leaf maturity (Ameen, 2018). Valencia orange trees in March usually have a greater percentage of older leaves, thus the low absorbance efficiency than those carried by the trees in September.

It can be noticed that the iron content of the orange leaves was not affected by applying chelated manganese in the first season but the same applications in the second seasons caused a marked reduction in the iron content (Table 5).

Data in Table (5) revealed that the zinc content showed no definite trend in both the two seasons due to the rate of manganese spray or number of applications. 
Table (5): Leaf concentration of $\mathrm{Fe}, \mathrm{Mn}$, and $\mathrm{Zn}(\mathrm{ppm})$ concentration of Valencia orange sprayed with chelated manganese in both 2017 and 2018 seasons

\begin{tabular}{|c|c|c|c|c|c|c|c|c|}
\hline \multirow{3}{*}{ Chelated iron (\%) } & \multicolumn{8}{|c|}{ Fe $\%$} \\
\hline & \multicolumn{2}{|c|}{ Mar. } & \multicolumn{2}{|c|}{ Mar, June } & \multicolumn{2}{|c|}{ Mar, June, Sept. } & \multicolumn{2}{|c|}{ Av. } \\
\hline & 2017 & 2018 & 2017 & 2018 & 2017 & 2018 & 2017 & 2018 \\
\hline Control & 7.4 & 9.0 & 8.1 & 7.6 & 6.6 & 7.9 & 7.4 & 8.2 \\
\hline T1 & 11.2 & 11.8 & 12.0 & 12.0 & 11.8 & 12.8 & 12.8 & 12.7 \\
\hline $\mathbf{T} 2$ & 12.8 & 15.0 & 13.8 & 15.1 & 13.8 & 14.0 & 14.0 & 14.7 \\
\hline T3 & 17.0 & 17.8 & 13.1 & 14.8 & 16.3 & 17.7 & 17.7 & 16.7 \\
\hline Mean & 12.1 & 13.4 & 11.7 & 12.4 & 12.1 & 13.1 & 13.1 & 13.1 \\
\hline \multirow{3}{*}{\multicolumn{7}{|c|}{$\begin{array}{l}\text { LSD (0.05): Levels of manganese spray (A) } \\
\text { LSD (0.05): No. of applications (B) } \\
\text { LSD (0.05): Interaction: }(A) \times(B)\end{array}$}} & 4.31 & 3.17 \\
\hline & & & & & & & 2.01 & 2.00 \\
\hline & & & & & & & 3.16 & 1.78 \\
\hline
\end{tabular}

\begin{tabular}{|c|c|c|c|c|c|c|c|c|}
\hline \multicolumn{9}{|c|}{ Mn \% } \\
\hline \multirow{2}{*}{ Chelated iron (\%) } & \multicolumn{2}{|c|}{ Mar. } & \multicolumn{2}{|c|}{ Mar, June } & \multicolumn{2}{|c|}{ Mar, June, Sept. } & \multicolumn{2}{|c|}{ Av. } \\
\hline & 2017 & 2018 & 2017 & 2018 & 2017 & 2018 & 2017 & 2018 \\
\hline Control & 7.5 & 8.2 & 8.0 & 7.0 & 8.0 & 7.3 & 7.8 & 7.5 \\
\hline T1 & 6.8 & 8.0 & 6.0 & 6.7 & 7.0 & 7.1 & 6.6 & 7.3 \\
\hline $\mathbf{T 2}$ & 7.8 & 6.2 & 7.1 & 6.2 & 6.8 & 6.2 & 7.2 & 6.2 \\
\hline T3 & 9.7 & 7.0 & 6.8 & 6.0 & 6.8 & 6.4 & 7.8 & 6.5 \\
\hline Mean & 7.9 & 7.3 & 7.0 & 6.5 & 7.1 & 6.7 & 7.3 & 6.9 \\
\hline \multicolumn{7}{|c|}{$\begin{array}{l}\text { LSD (0.05): Levels of manganese spray (A) } \\
\text { LSD (0.05): No. of applications (B) } \\
\text { LSD (0.05): Interaction: }(A) \times(B)\end{array}$} & $\begin{array}{l}\text { N.S. } \\
\text { N.S. } \\
\text { N.S. }\end{array}$ & $\begin{array}{l}\text { N.S. } \\
\text { N.S. } \\
\text { N.S. }\end{array}$ \\
\hline
\end{tabular}

\begin{tabular}{lcccccccc}
\hline \multicolumn{10}{c}{ Zn \% } \\
\hline \multirow{2}{*}{ Chelated iron (\%) } & \multicolumn{1}{c}{ Mar. } & \multicolumn{1}{c}{ Mar, June } & Mar, June, Sept. & \multicolumn{3}{c}{ Av. } \\
\cline { 2 - 9 } & $\mathbf{2 0 1 7}$ & $\mathbf{2 0 1 8}$ & $\mathbf{2 0 1 7}$ & $\mathbf{2 0 1 8}$ & $\mathbf{2 0 1 7}$ & $\mathbf{2 0 1 8}$ & $\mathbf{2 0 1 7}$ & $\mathbf{2 0 1 8}$ \\
\hline Control & 100.3 & 99.8 & 103.0 & 105.1 & 103.0 & 105.1 & 102.1 & 3.4 \\
T1 & 104.7 & 87.0 & 76.7 & 91.0 & 87.0 & 92.1 & 89.5 & 90.1 \\
T2 & 99.8 & 92.1 & 87.0 & 91.0 & 87.0 & 76.7 & 91.3 & 89.6 \\
T3 & 107.0 & 76.7 & 99.8 & 82.1 & 102.2 & 87.0 & 102.9 & 81.9 \\
\hline Mean & 102.9 & 88.9 & 91.6 & 32.2 & 94.7 & 90.3 & 96.4 & 88.7 \\
\hline LSD (0.05): Levels of manganese spray (A) & & & & & 33.01 & 26.01 \\
LSD (0.05): No. of applications (B) & & & & & & 12.11 & 7.80 \\
LSD (0.05): Interaction: (A) $\times(\mathbf{B})$ & & & & & & & 7.16 & 10.15 \\
\hline
\end{tabular}

\section{REFERENCES}

AOAC (2000). Official Methods of Analysis. Association of Official Analytical Chemists. $20^{\text {th }}$ ed. Washington, D.C., USA.

Abd-Allah, A. S. E. (2006). Effect of spraying some macro and micronutrients on fruit set, yield and fruit quality of Washington Navel orange trees. J. of Applied Sciences Research, 2(1): 26-39.
Ameen, R. A. (2018). Studies on factors affecting water relations in orange trees. Ph.D. Dissertation, Fac. Agric., Cairo Univ.

Boman, B. J. (2001). Foliar nutrient sprays influence yield and size of 'Valencia' orange Proc. Fla. State Hort. Soc., 114: 83-88.

Boman, B. J. (2002). KNO3 foliar application to 'Sunburst' Tangarine. Proc. Fla. Hort. Soc. 115: 6-9.

Brown, J. D. and O. Lilliland (1946). Rapid determination of potassium and sodium in 
plant material and soil extracts by flame photometer. Proc. Amer. Soc. Hort. Sci., 48: 341-346.

Camp, A. F. and Michael Peach (1939). Manganese deficiency in citrus in Florida, Amer. Soc. Hort. Sci. proc., 136: 81-85.

Chapman, H. D. (1960). Leaf and soil analysis as guides for citrus fertilizer practices in Southern California orchards. California Agric., 14(10): 13-14.

Chapman, H. D. and P. F. Pratt (1965). Methods of analysis for soil, plants and waters. Div. agric. Sci., Univ. of Calif., Berkeley.

Cicala, A. and V. Catara (1994). Potassium fertilization effects on yield, fruit quality and mineral composition of leaves of Tarocco orange trees. Proceeding of the International Society of Citriculture: Volume 2. Cultural practices, diseases and their control: $7^{\text {th }}$ International Citrus congress, Acireale, Italy, 8-13 March, 1994, 618-620.

Clarkson, D. T. and J. B. Hanson (1980). The mineral nutrition of higher plants. Ann. Rev. Plant Physiol., 31: 289-298.

Cottenie, A., M. Verloo, M. Velghe and R. Camerlynck (1982). Chemical Analysis of Plant and Soil. Ghent, Belgium, Laboratory of Analytical and Agro-chemistry. State Univ., pp. 200-210.

Datta, Chittatosh (1968). Plant Physiology, Affiliated East-West Press Private Ltd., New Delhi, India. Pp. 162-263.

Dawood, S. A., M. M. El-Hamady, S. A. G. El-Siada and A. M. Hamissa (2001). Response of Washington Navel orange trees grown on slightly alkaline clay soils to magnesium rate, methods and number of applications. Egyptian Journal of Agric. Res., 79(3): 10591073.

Devlin, R. M. (1972). Plant Physiology. Affiliated East-West Press Private Ltd, New Delhi, India. $442 \mathrm{pp}$.

Dutt, S. and H. R. Bohambota (1971). Effect of different concentrations of iron the incidence of chlorosis in sweet orange (Citrus sinensis). Ind. J. Hort., 28L: 16-21.

El-Fouly, M. M., A. I. Rezk, O. A. Nofal and E. A. A. Abou ElNour (2010). Depletion of magnesium in Egyptian soils, its content in crops and estimated needs. African Journal of Agricultural Research, 5(10): 1060-1067.

Evenhuis, B. and P. W. Dewaard (1980). Principles and practices in plants analysis F.A.O. Soil and Bull., 38: 163-172.

Haggag, M. N., H. A. El-Shamy and E. M. El-Azab (1987). Magnesium influences on leaf chlorophyll, leaf mineral composition, yield and fruit quality of Washington Navel oranges in Egypt. Alex. J. of Agric Res., 32(3): 189-198.
Hilgeman, R. H. (1955). Correction of iron chlorosis with iron Chelates in Arizona Calif. Citr., 54L: 406-428.

Huang, F. S., H. S. Zhang, H. M. Qian and F. Yi (1995). Study on the effects of organic manures and leaf spraying $\mathrm{P}$ and $\mathrm{k}$ on the fruit quality of extra-early Satsuma mandarin. China Citrus. 24(2): 31-32.

Labanuskas, C. K., W. W. Jones and T. W. Embleton (1969). Low residue micronutrient nutritional sprays for citrus. Proc. $1^{\text {st }}$ Int. citrus. Sym., Riverside, Calif., 3L: 15351542.

Maksoud, M. A., M. M. S. Saleh, L. F. Haggag and B. N. Boutros (2003). Effects of iron and potassium fertilization on Balady mandarin trees grown in calcareous soil. Annals of Agricultural Science (Cairo), 48(2): 741-746.

Manchand, H. R., N. S. Randhawa and U. C. Skukla (1971). Effect of foliar application of different micronutrient in relation to sources of $\mathrm{N}$ and the chemical composition of sweet orange leaves. Ind. Jour. Hort., 28(2): 100-107.

Meyer, R. S and D. B. Anderson (1970). Plant physiology. Affiliated East-West Press Private Ltd., New Delhi, India., 257 pp.

Miller, J., J. Maritz and P. Bird (1998). Could potassium be used to improve Midknight Valencia and Robyn Navel. Neltropika Bulletin, 302: 32-33.

Nasr, A. F. S. (1982). Effect of some nutrients on growth, flowering and fruit quality of Washington navel oranges. Ph.D. Dissertation, Fac. Agric., Cairo Univ.

Parker, E. R. and R. W. Southwick (1941). Manganese deficiency in citrus. Proc. Amer. Soc. Hort. Sci., 39: 51-58.

Platt, R. G. (1968). Micronutrient deficiencies of citrus. Calif. Agri. Expt. Stn. Bull., 141.

Quaggio, J. A., D. Mattose Jr., H. Cantarella, E. L. E. Almeida and S. A. B. Cardoso (2002). Lemon yield and fruit quality affected by $\mathrm{N}$ P K fertilization. Scientia Horticulturae, 96: 151-162.

Rattanpal, H. S., S. Rani and H. S. Dhaliwal (2008). Effect of potassium and 2,4-D on yield and fruit quality of Kinnow mandarin. Environment and Ecology, 26(2): 709-715.

Snedecor G. W. and W. G. Cochran (1980). Statistical Methods. $7^{\text {th }}$ ed., Iowa State Univ. Press, Amer. Iowa, U.S.A.

Wallace, A. (1966). Chelated metals for supplying micronutrients of fruits crops. Childers (ed.) Fruit nutrition. Horticulture Publications, Rutgers Univ., New Jersey.

Yasseen. M. and A. Manzoor (2010). Nutrition management in citrus: Effect of multinutrients foliar feeding on the yield of Kinnow at different locations. Pak. J. Bot., 42(3): 1863-1870. 


\section{استجابة أشجار البرتقال الصيفي الفالنسيا للرش الورقي بالمنجنيز المخلبي \\ علي محمد إبراهيم \\ معهد بحوث البساتين، مريز البحوث الزمبر إينة، الجيزة، مصر}

حجم الثمار هو أحد العوامل التي تحدد القيمة التسويقية لمحصول الموالح. أجريت الدراسة على أثجار البرتقال الصيفي فالنسيا

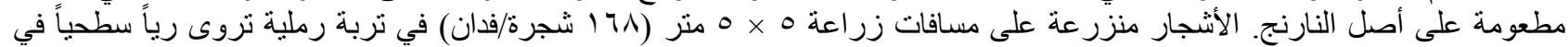

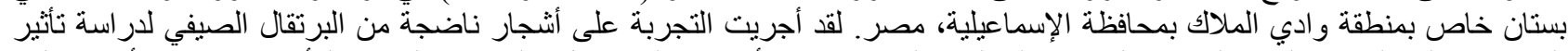

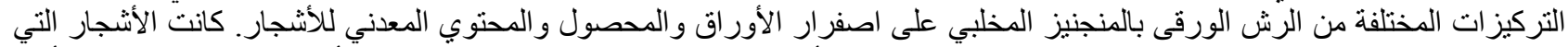

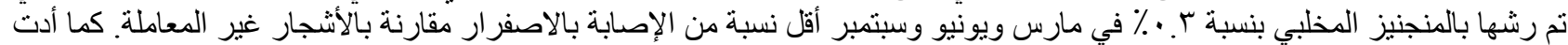

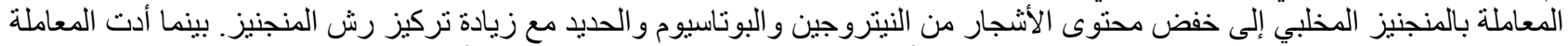

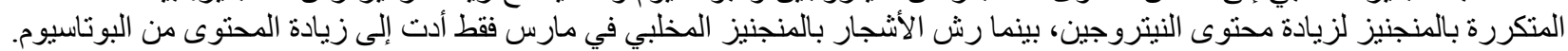

